\title{
Increasing evidence for involvement of SV40 in human cancer
}

\author{
Janet S. Butel* \\ Department of Molecular Virology and Microbiology, \\ Baylor College of Medicine, Houston, TX 77030, USA
}

SV40, a small DNA virus, is known to possess strong oncogenic potential. Millions of people were exposed to SV40 as an unknown contaminant of some early poliovaccines. This article briefly summarizes the increasing evidence of the association of SV40 with certain types of human cancer, including mesotheliomas and brain tumors. Unanswered questions pertaining to the pathogenesis of human infections by SV40 and the functional role of the virus in tumor development are noted. It is concluded that SV40 should be considered a candidate human tumor virus and that vigorous efforts to clarify the role of the virus in human disease should be supported.

\section{Introduction}

The polyomavirus SV40 is a highly tumorigenic DNA virus, with the large T-antigen functioning as a potent viral transforming protein (Fig. 1) $[4,5,8,11$, 30]. Although SV40 was inadvertantly administered to millions of people as an unrecognized contaminant of many poliovaccines between 1955 and early 1963 [8, $15,41]$, no short-term adverse effects on human health were recognized and those observations led to the belief that SV40 was harmless in humans. It is time to re-evaluate that conclusion.

Occasional reports of the detection of SV40 in human brain tumors started appearing in the 1970's [8], but limitations of available technology dampened the impact of those observations. The first report of detection of SV40 DNA in human brain tumors using polymerase chain reaction (PCR) and sequence analysis technologies appeared in 1992 [3]. Subsequently,

\footnotetext{
* Address for correspondence: Janet S. Butel, Ph.D., Department of Molecular Virology and Microbiology, Mail Stop BCM385, Baylor College of Medicine, One Baylor Plaza, Houston, TX 77030, USA. Tel.: +1 713798 3003; Fax: +1 713798 5019; E-mail: jbutel@bcm.tmc.edu.
}

many independent studies reported similar findings involving several types of tumors $[1,8,10,25]$.

This paper will be a brief synopsis of the evidence linking SV40 to human tumors. Although some have been skeptical of the validity of the general observations $[43,49]$ and the evidence does not yet constitute proof of viral etiology, it is the opinion of this author that the totality of data is persuasive and deserves serious consideration. The potential benefit to the public, if the virus were to be established as a factor in human carcinogenesis, would be significant and warrants that these leads be vigorously pursued with the full support of the NIH.

\section{Independent studies and complementary approaches}

There have been over 50 reports of the detection of SV40 DNA in human tumors $[1,8,10,25]$. These reports have focused predominantly on mesotheliomas, brain tumors, and osteosarcomas and have originated from geographically distinct regions of the world. As an example of the reproducibility of detection of SV40 sequences in certain types of tumors, results involving brain tumors are summarized in Table 1.

Estimates of SV40 positivity among different types of human tumors vary widely, but generally are above $50 \%$ for mesotheliomas and certain brain tumors and about $35 \%$ for bone tumors $[1,25]$.

Complementary technical approaches have indicated the presence of SV40 in human tumors. These approaches have included (i) PCR assays of tumor cell DNA using primer sets directed against one or more regions of the SV40 genome, (ii) sequence or Southern blot analysis of PCR products, (iii) immunohistochemistry (IHC) using antibodies to SV40 T-antigen, (iv) protein extractions followed by Western blot assays to detect SV40 T-antigen, (v) in situ hybridization to detect SV40 messenger RNA, (vi) microdissection of mesothelioma samples to separate tumor cells from normal cells, (vii) isolation of infectious virus 


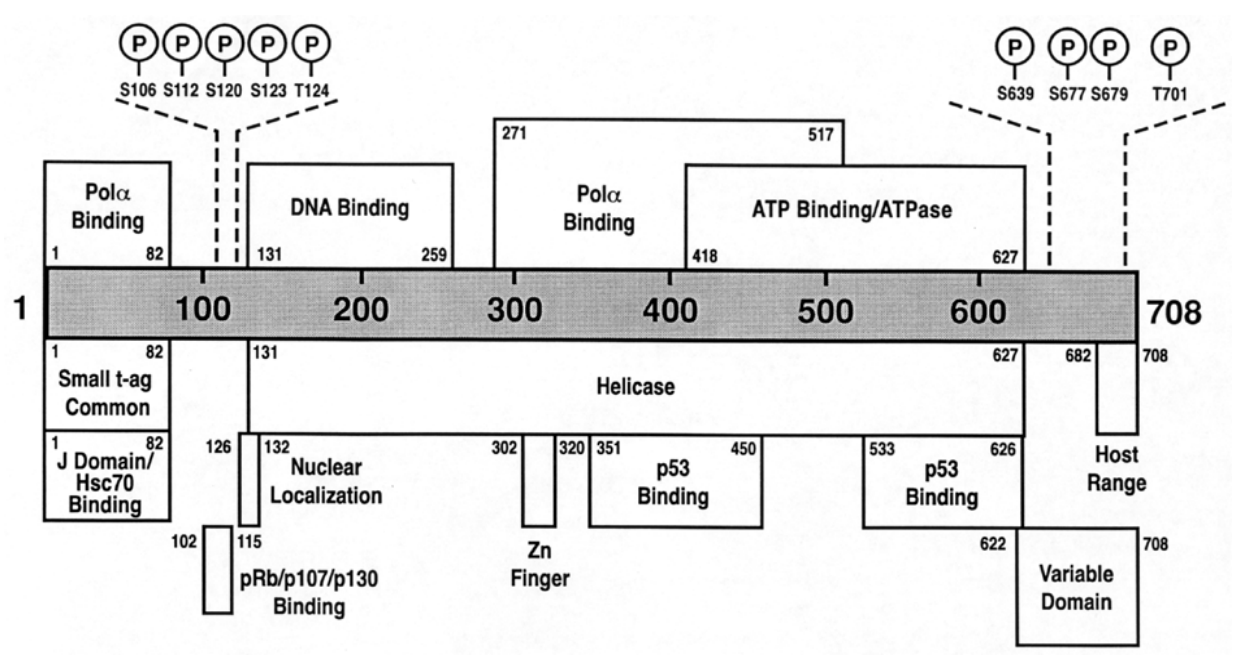

Fig. 1. Functional domains of SV40 large tumor antigen (T-ag). The numbers given are the amino acid residues using the numbering system for SV40-776. Regions are indicated as follows. Small t-ag Common: region of large T-ag encoded in the first exon; the amino acid sequence in this region is common to both large T-ag and small t-ag. Pol $\alpha$ Binding: regions required for binding to polymerase $\alpha$-primase. J Domain/Hsc70 Binding: region required for binding the heat shock protein hsc70. pRb/p107/p130 Binding: region required for binding of the Rb tumor suppressor protein, and the Rb-related proteins p107 and p130. Nuclear Localization: contains the nuclear localization signal. DNA Binding: minimal region required for binding to SV40 Ori DNA. Helicase: region required for full helicase activity. Zn Finger: region which binds zinc ions. p53 Binding: regions required for binding the p53 tumor suppressor protein. ATP Binding/ATPase: region containing the ATP binding site and ATPase catalytic activity. Host Range: region defined as containing the host range and Ad helper functions. Variable Domain: region containing amino acid differences among viral strains. The circles containing a P indicate sites of phosphorylation found on large T-ag expressed in mammalian cells. $\mathrm{S}$ indicates a serine and $\mathrm{T}$ indicates a threonine residue. Reproduced from Butel and Lednicky [8] as modified there from Stewart et al. [47].

from tumor samples, and (viii) inhibition of SV40positive tumor cell proliferation by an SV40 early region antisense construct. A recent multi-institutional study in which several participating groups detected SV40 DNA in coded mesothelioma specimens provided strong evidence for inter-laboratory reproducibility of results [52].

\section{Common arguments have been ruled out}

An argument raised against the observation that SV40 is present in human tumors is that the tumorassociated virus has been misidentified, i.e., that it is not SV40 but is either one of the known human polyomaviruses (JCV or BKV) or a new, previously unrecognized virus. It is certainly possible that JCV or BKV are present in some human tumors and may be etiologically important $[2,23,28]$. In some studies in which SV40-specific primers were used, confirmatory tests were not carried out to prove that amplified sequences were actually SV40 specific, but in many studies, the PCR products were proven by sequence analysis or Southern blot hybridization to be of SV40 origin [1, 25]. Up to four separate sections of the viral genome have been amplified from some tumors [31,32], making it highly likely that authentic SV40 was present in those tumors. SV40 genomic DNA was cloned directly from a meningioma [27] and infectious SV40 was rescued from a choroid plexus carcinoma [31]; these human brain tumor isolates have been sequenced in entirety and shown to be authentic SV40 [48]. Thus, SV40 sequences detected in some human tumors have been unambiguously discriminated from those of other polyomaviruses.

Another frequently posed argument is that the positive tumor results are due to laboratory contamination of tumor specimens. Laboratory contamination is a valid concern, given the sensitivity of the PCR assay, the presence of SV40-based plasmids in many laboratories, and the possibility of cross-contamination of PCR reactions with positive control plasmids. It is not possible to know whether contamination may have occurred in any of the studies reporting positive results, but this potential problem as the explanation for all virus-positive tumors has been ruled out (Table 2). Reports often describe extensive precautions that were taken to avoid contamination of samples during specimen processing or analysis, such as the use of dedicated rooms from which plasmids and viruses were 
Table 1

Detection of SV40 in human brain tumors

\begin{tabular}{lllr}
\hline \multirow{2}{*}{ Tumor type } & \multicolumn{2}{c}{ No. positive/No. tested (\%) } & Ref. \\
\cline { 2 - 3 } & SV40 DNA & SV40 T-antigen & \\
\hline Brain tumors & $11 / 32(34)$ & & 22 \\
Brain tumors & $14 / 53(26)$ & $18 / 68(26)$ & 18 \\
Astrocytoma & $1 / 8(12)$ & & 26 \\
Astrocytoma & $8 / 17(47)$ & & 34 \\
Astrocytoma & & $11 / 15(73)$ & 54 \\
Choroid plexus & $10 / 20^{*}(50)$ & $4 / 5(80)$ & 3 \\
Choroid plexus & $5 / 6(83)$ & & 34 \\
Choroid plexus & $6 / 16(38)$ & & 21 \\
Choroid plexus & $0 / 7(0)^{* *}$ & & 38 \\
Ependymoma & $10 / 11(91)$ & $3 / 6(50)$ & 3 \\
Ependymoma & $8 / 11(73)$ & & 34 \\
Ependymoma & $4 / 13(31)$ & & 51 \\
Ependymoma & & $8 / 8(100)$ & 53 \\
Ependymoma & $1 / 25(<1)$ & & 21 \\
Ependymoma & $9 / 16(56)$ & & 38 \\
Ependymoma & $0 / 10(0)^{* *}$ & & 34 \\
Glioblastoma & $10 / 30(33)$ & & 21 \\
Glioblastoma & $7 / 28(25)$ & & 38 \\
Glioblastoma & $0 / 13(0)^{* *}$ & & 54 \\
Glioblastoma & & $4 / 8(50)$ & \\
\hline
\end{tabular}

${ }^{*}$ Infectious SV40 recovered from one tumor.

** Tumors from Finland.

Table 2

Evidence against laboratory contamination of SV40-positive human tumor specimens

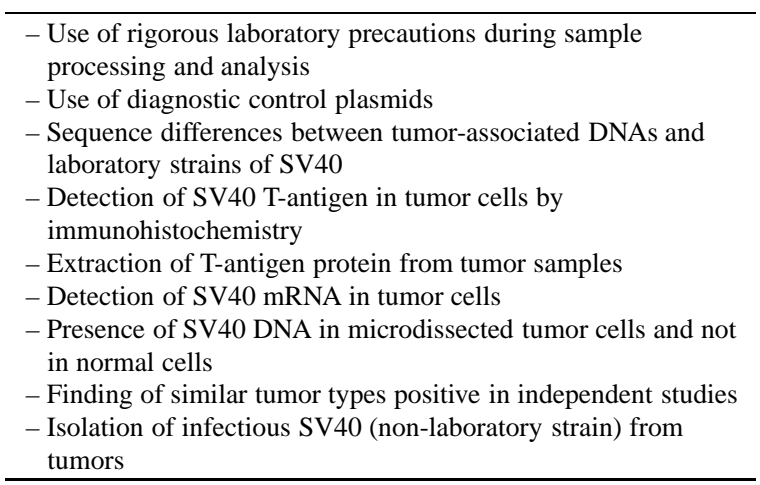

excluded. Positive control plasmids containing diagnostic engineered restriction sites [29] have been used to allow differentiation of sequences amplified from tumors from the positive controls.

The most definitive evidence against contamination comes from sequence analyses that revealed that tumor-associated sequences could be distinguished from known laboratory strains of SV40 [8,31,32,48]. Viral DNA detected in tumors often has an archetypal regulatory region arrangement, similar to the arrangement of natural isolates, without the duplications in the enhancer that are typical of laboratory strains. A variable domain at the $\mathrm{C}$-terminus of the $\mathrm{T}$-antigen gene can be used to differentiate SV40 strains [47] and, in the majority of cases, tumor-associated sequences have differed from all known laboratory strains.

IHC assays have detected the expression of T-antigen in tumor cells $[3,9,12,33,52]$, T-antigen protein has been extracted from some tissue specimens and shown to be complexed with p53 [9,54], and SV40 mRNA expression has been demonstrated in tumors [9]. None of these results would be possible if samples were accidentally contaminated with SV40 virus or plasmid DNA during sample preparation.

Microdissection of mesothelioma samples followed by PCR assays detected SV40 DNA in the tumor cells and not in adjacent, nonmalignant cells $[45,46]$. If laboratory contamination had occurred, viral sequences presumably would have been distributed randomly. Independent studies have consistently found ependymomas and choroid plexus tumors to have higher SV40 positivity rates than glioblastomas or medulloblastomas, observations that are not compatible with laboratory contamination, which would be expected to be distributed randomly among samples, regardless of tumor type.

Other concerns routinely raised about the etiologic significance of virus-cancer associations do not apply to this system [5]. There is agreement that SV40 is tumorigenic and that SV40 can transform human cells [5, $8,11]$. Strong evidence exists that SV40 can infect humans, based on serological surveys $[7,8,17,20,24,42$, $44,55]$, detection of SV40 DNA in pediatric renal transplants [6], and excretion of virus by infants who were recipients of SV40-contaminated poliovaccines [35], in addition to the detection of SV40 DNA in human tumors $[1,8,25]$. The fact that SV40 DNA has been found associated with several histological types of tumors is not evidence against viral specificity; although some human tumor viruses (such as hepatitis B virus) produce a single type of cancer, others (such as EpsteinBarr virus) are associated with multiple tumor types [5]. SV40 is able to induce tumors in several different tissues in rodents, and the human tumors found to contain SV40 DNA are the same tumor types as those produced in rodents following virus inoculation [8].

\section{The conundrum of negative studies and unexpected findings}

Several studies have reported failures at detection or infrequent detection of SV40-related sequences in mesotheliomas or brain tumors [13,19,37,38,49,53] (Table 1). Assuming that the positive reports are accurate, explanations need to be considered for the negative 
studies. Negative results could reflect unrecognized variables, perhaps including (i) the patient population studied, (ii) the geographic origin of the tumors, (iii) the age of the patients, (iv) the numbers and types of tumors examined, (v) sample collection or processing (with deparaffinization and DNA extraction methods significant technical variables) [29], or (vi) the sensitivity of analytic methods employed (such as amounts of DNA tested or the numbers of PCR cycles used) [29]. Geographic differences may be significant and may reflect variations in exposure to the virus and/or environmental cofactors. For example, mesotheliomas from Finland and Turkey and brain tumors from Finland have been found to be SV40 negative $[13,19,38]$, whereas the same investigators detected SV40 DNA in similar tumors from other countries $[13,21,52]$ (Table 1). It has been noted that SV40-contaminated poliovaccines were not used in Finland and Turkey [13,19].

Several epidemiology studies have failed to detect an elevated risk of cancer among recipients of potentially contaminated poliovaccines $[16,36,39,50]$. However, these analyses have not ruled out SV40 as a human pathogen. Cohort-based epidemiological studies have certain limitations; as poliovaccines were not uniformly contaminated with SV40, it cannot be known which individuals in the "exposed" cohort actually were exposed to SV40 or to what level of infectious virus. These studies have assumed that no human exposure to SV40 has occurred except through the vaccines used from 1955 to 1963 . As there is strong evidence that humans continue to be exposed to SV40, perhaps by horizontal transmission, the cohort analyses are further complicated. A recent survey by Fisher et al. [14], in contrast, concluded that there may be an increased incidence of brain and bone tumors among recipients of the contaminated poliovaccines.

Discrepant results and unexpected observations illustrate that there is much we do not know about SV40 and human infections. Until pathogenesis parameters are defined and technical variables are identified, it is to be expected that there will be conflicting reports and differing interpretations of virus-tumor associations [5].

\section{Conclusions}

At this time, SV40 should be considered a candidate human cancer virus. A compelling case can be made that SV40 infects humans today and may be found in association with certain types of human tumors. However, the biological role the virus may play in the etiopathogenesis of those tumors remains to be determined. Unanswered questions include: (i) the source(s) of virus causing human infections, (ii) routes of viral transmission, (iii) tissue distribution of viral infection in humans, (iv) geographic differences in the prevalence of virus infections, (v) predisposing host factors that influence susceptibility to infection and disease, (vi) the biological effects of different virus variants, (vii) the state of viral DNA in tumor cells, (viii) expression of viral genes during tumorigenesis, and (ix) possible co-factors involved in cancer causation.

During the early stages of unraveling new virusdisease associations, discordant reports are to be expected [5]. However, such discrepancies should not paralyze scientific inquiry and prevent exploration of potentially important human disease leads. Considering the wealth of information accumulated about SV40 as an oncogenic virus and the mounting evidence of SV40 infections in humans, the possible involvement of the virus in human tumor development is a credible hypothesis that deserves to be addressed without delay.

The significance of establishing an SV40 role in the etiology of human cancer would be profound. Viral markers could be used for the diagnosis of tumors having a viral component and might provide useful prognostic information; preliminary data, in fact, suggest that SV40 is associated with poorer survival in patients with mesothelioma [40]. The encyclopedic knowledge of the functions of T-antigen could lead to cancer treatments targeted toward the viral transforming protein. Finally, new means of cancer prevention could be developed aimed at blocking virus infection, including viral vaccine approaches.

\section{References}

[1] A.S. Arrington and J.S. Butel, SV40 and human tumors, in: The Human Polyomaviruses JC, BK, and SV40: Molecular and Clinical Perspectives, K. Khalili and G.L. Stoner, eds, John Wiley \& Sons, New York, 2001, in press.

[2] G. Barbanti-Brodano, F. Martini, M. De Mattei, L. Lazzarin, A. Corallini and M. Tognon, BK and JC human polyomaviruses and simian virus 40: natural history of infection in humans, experimental oncogenicity, and association with human tumors, Advances in Virus Research 50 (1998), 69-99.

[3] D.J. Bergsagel, M.J. Finegold, J.S. Butel, W.J. Kupsky and R.L. Garcea, DNA sequences similar to those of simian virus 40 in ependymomas and choroid plexus tumors of childhood, New England Journal of Medicine 326 (1992), 988-993.

[4] J.S. Butel, Simian virus 40 (Papovaviridae), in: Encyclopedia of Virology, (2nd ed.), R.G. Webster and A. Granoff, eds, Academic Press, London, 1999, pp. 1647-1656.

[5] J.S. Butel, Viral carcinogenesis: revelation of molecular mechanisms and etiology of human disease, Carcinogenesis 21 (2000), 405-426. 
[6] J.S. Butel, A.S. Arrington, C. Wong, J.A. Lednicky and M.J. Finegold, Molecular evidence of simian virus 40 infections in children, Journal of Infectious Diseases 180 (1999), 884-887.

[7] J.S. Butel, S. Jafar, C. Wong, A.S. Arrington, A.R. Opekun, M.J. Finegold and E. Adam, Evidence of SV40 infections in hospitalized children, Human Pathology 30 (1999), 14961502 .

[8] J.S. Butel and J.A. Lednicky, Cell and molecular biology of simian virus 40: Implications for human infections and disease, Journal of the National Cancer Institute 91 (1999), 119 134.

[9] M. Carbone, P. Rizzo, P.M. Grimley, A. Procopio, D.J. Mew, V Shridhar, A. de Bartolomeis, V. Esposito, M.T. Giuliano, S.M Steinberg, A.S. Levine, A. Giordano and H.I. Pass, Simian virus-40 large- $\mathrm{T}$ antigen binds $\mathrm{p} 53$ in human mesotheliomas, Nature Medicine 3 (1997), 908-912.

[10] M. Carbone, P. Rizzo and H.I. Pass, Simian virus 40, poliovaccines and human tumors: a review of recent developments, Oncogene 15 (1997), 1877-1888.

[11] C.N. Cole, Polyomavirinae: the viruses and their replication, in: Fields Virology, (3rd ed.), B.N. Fields, D.M. Knipe, P.M Howley, R.M. Chanock, J.L. Melnick, T.P. Monath, B. Roizman and S.E. Straus, eds, Lippincott-Raven, Philadelphia, 1996, pp. 1997-2025.

[12] K. Dhaene, A. Verhulst and E. Van Marck, SV40 large Tantigen and human pleural mesothelioma: Screening by polymerase chain reaction and tyramine-amplified immunohistochemistry, Virchows Archiv an International Journal of Pathology 435 (1999), 1-7.

[13] S. Emri, T. Kocagoz, A. Olut, Y. Güngen, L. Mutti and Y.I. Baris, Simian Virus 40 is not a cofactor in the pathogenesis of environmentally induced malignant pleural mesothelioma in Turkey, Anticancer Research 20 (2000), 891-894.

[14] S.G. Fisher, L. Weber and M. Carbone, Cancer risk associated with simian virus 40 contaminated polio vaccine, Anticancer Research 19 (1999), 2173-2180.

[15] J.F. Jr. Fraumeni, F. Ederer and R.W. Miller, An evaluation of the carcinogenicity of simian virus 40 in man, Journal of the American Medical Association 185 (1963), 713-718.

[16] E. Geissler, SV40 and human brain tumors, Progress in Medical Virology 37 (1990), 211-222.

[17] E. Geissler, P. Konzer, S. Scherneck and W. Zimmermann, Sera collected before introduction of contaminated polio vaccine contain antibodies against SV40, Acta Virologica 29 (1985), 420-423.

[18] E. Geissler, S. Scherneck, H. Prokoph, W. Zimmermann and W. Staneczek, SV40 in human brain tumors: risk factor or passenger? in: The Role of Viruses in Human Cancer, (Vol. II), G. Giraldo and E. Beth, eds, Elsevier, Amsterdam, 1984, pp. 265279.

[19] A. Hirvonen, K. Mattson, A. Karjalainen, T. Ollikainen, L. Tammilehto, T. Hovi, H. Vainio, H.I. Pass, I. Di Resta, M. Carbone and K. Linnainmaa, Simian virus 40 (SV40)-like DNA sequences not detectable in Finnish mesothelioma patients not exposed to SV40-contaminated polio vaccines, Molecular Carcinogenesis 26 (1999), 93-99.

[20] L.B. Horvath, SV40 neutralizing antibodies in the sera of man and experimental animals, Acta Virologica 16 (1972), 141146.

[21] H. Huang, R. Reis, Y. Yonekawa, J.M. Lopes, P. Kleihues and H. Ohgaki, Identification in human brain tumors of DNA sequences specific for SV40 large T antigen, Brain Pathology 9 (1999), 33-42.
22] H. Ibelgaufts and K.W. Jones, Papovavirus-related RNA sequences in human neurogenic tumours, Acta Neuropathologica 56 (1982), 118-122.

[23] M.J. Imperiale, The human polyomaviruses, BKV and JCV: Molecular pathogenesis of acute disease and potential role in cancer, Virology 267 (2000), 1-7.

[24] S. Jafar, M. Rodriguez-Barradas, D.Y. Graham and J.S. Butel, Serological evidence of SV40 infections in HIV-infected and HIV-negative adults, Journal of Medical Virology 54 (1998), 276-284.

[25] B. Jasani, A. Cristaudo, S.A. Emri, A.F. Gazdar, A. Gibbs, B. Krynska, C. Miller, L. Mutti, C. Radu, M. Tognon and A. Procopio, Association of SV40 with human tumours, Seminars in Cancer Biology 11 (2001), 49-61.

[26] P. Krieg, E. Amtmann, D. Jonas, H. Fischer, K. Zang and G. Sauer, Episomal simian virus 40 genomes in human brain tumors, Proceedings of the National Academy of Sciences USA 78 (1981), 6446-6450.

[27] P. Krieg and G. Scherer, Cloning of SV40 genomes from human brain tumors, Virology 138 (1984), 336-340.

[28] B. Krynska, L. Del Valle, S. Croul, J. Gordon, C.D. Katsetos, M. Carbone, A. Giordano and K. Khalili, Detection of human neurotropic JC virus DNA sequence and expression of the viral oncogenic protein in pediatric medulloblastomas, Proceedings of the National Academy of Sciences USA 96 (1999), 1151911524.

[29] J.A. Lednicky and J.S. Butel, Consideration of PCR methods for the detection of SV40 in tissue and DNA specimens, $D e$ velopments in Biological Standardization 94 (1998), 155-164.

[30] J.A. Lednicky and J.S. Butel, Polyomaviruses and human tumors: a brief review of current concepts and interpretations, Frontiers in Bioscience 4 (1999), 153-164.

[31] J.A. Lednicky, R.L. Garcea, D.J. Bergsagel and J.S. Butel, Natural simian virus 40 strains are present in human choroid plexus and ependymoma tumors, Virology 212 (1995), 710717.

[32] J.A. Lednicky, A.R. Stewart, J.J. Jenkins, III, M.J. Finegold and J.S. Butel, SV40 DNA in human osteosarcomas shows sequence variation among T-antigen genes, International Journal of Cancer 72 (1997), 791-800.

[33] F. Martini, R. Dolcetti, A. Gloghini, L. Iaccheri, A. Carbone, M. Boiocchi and M. Tognon, Simian-virus-40 footprints in human lymphoproliferative disorders of $\mathrm{HIV}^{-}$and $\mathrm{HIV}^{+} \mathrm{pa}-$ tients, International Journal of Cancer 78 (1998), 669-674.

[34] F. Martini, L. Iaccheri, L. Lazzarin, P. Carinci, A. Corallini, M. Gerosa, P. Iuzzolino, G. Barbanti-Brodano and M. Tognon, SV40 early region and large $\mathrm{T}$ antigen in human brain tumors, peripheral blood cells, and sperm fluids from healthy individuals, Cancer Research 56 (1996), 4820-4825.

[35] J.L. Melnick and S. Stinebaugh, Excretion of vacuolating SV40 virus (papova virus group) after ingestion as a contaminant of oral poliovaccine, Proceedings of the Society for Experimental Biology and Medicine 109 (1962), 965-968.

[36] E.A.J. Mortimer, M.L. Lepow, E. Gold, F.C. Robbins, G.J. Burton and J.F.J. Fraumeni, Long-term follow-up of persons inadvertently inoculated with SV40 as neonates, New England Journal of Medicine 305 (1981), 1517-1518.

[37] C. Mulatero, T. Surentheran, J. Breuer and R.M. Rudd, Simian virus 40 and human pleural mesothelioma, Thorax 54 (1999), 60-61.

[38] H. Ohgaki, H. Huang, M. Haltia, H. Vainio and P. Kleihues, More about: Cell and molecular biology of simian virus 40: implications for human infections and disease [Letter], Journal of the National Cancer Institute 92 (2000), 495-497. 
[39] P. Olin and J. Giesecke, Potential exposure to SV40 in polio vaccines used in Sweden during 1957: no impact on cancer incidence rates 1960 to 1993, Developments in Biological Standardization 94 (1998), 227-233.

[40] A. Procopio, L. Strizzi, G. Vianale, P. Betta, R. Puntoni, V. Fontana, G. Tassi, F. Gareri and L. Mutti, Simian virus-40 sequences are a negative prognostic cofactor in patients with malignant pleural mesothelioma, Genes, Chromosomes and Cancer 29 (2000), 173-179.

[41] K. Shah and N. Nathanson, Human exposure to SV40: review and comment, American Journal of Epidemiology 103 (1976), $1-12$.

[42] K.V. Shah, Evidence for an SV40-related papovavirus infection of man, American Journal of Epidemiology 95 (1972), 199-206.

[43] K.V. Shah, Does SV40 infection contribute to the development of human cancers? Reviews in Medical Virology 10 (2000), 31-43.

[44] K.V. Shah, H.L. Ozer, H.S. Pond, L.D. Palma and G.P. Murphy, SV40 neutralizing antibodies in sera of US residents without history of polio immunization, Nature 231 (1971), 448-449.

[45] N. Shivapurkar, T. Wiethege, I.I. Wistuba, S. Milchgrub, K.M Muller and A.F. Gazdar, Presence of simian virus 40 sequences in malignant pleural, peritoneal and noninvasive mesotheliomas, International Journal of Cancer 85 (2000), 743-745.

[46] N. Shivapurkar, T. Wiethege, I.I. Wistuba, E. Salomon, S. Milchgrub, K.M. Muller, A. Churg, H. Pass and A.F. Gazdar, Presence of simian virus 40 sequences in malignant mesotheliomas and mesothelial cell proliferations, Journal of Cellular Biochemistry 76 (1999), 181-188.

[47] A.R. Stewart, J.A. Lednicky, U.S. Benzick, M.J. Tevethia and J.S. Butel, Identification of a variable region at the carboxy terminus of SV40 large T-antigen, Virology 221 (1996), 355361.

[48] A.R. Stewart, J.A. Lednicky and J.S. Butel, Sequence analyses of human tumor-associated SV40 DNAs and SV40 viral isolates from monkeys and humans, Journal of Neurovirology 4 (1998), 182-193.

49] H.D. Strickler, J.J. Goedert, M. Fleming, W.D. Travis, A.E. Williams, C.S. Rabkin, R.W. Daniel and K.V. Shah, Simian virus 40 and pleural mesothelioma in humans, Cancer Epidemiology, Biomarkers and Prevention 5 (1996), 473-475.

[50] H.D. Strickler, P.S. Rosenberg, S.S. Devesa, J. Hertel, J.F.J. Fraumeni and J.J. Goedert, Contamination of poliovirus vaccines with simian virus 40 (1955-1963) and subsequent cancer rates (see comments), Journal of the American Medical Association 279 (1998), 292-295.

[51] S.O. Suzuki, M. Mizoguchi and T. Iwaki, Detection of SV40 $\mathrm{T}$ antigen genome in human gliomas, Brain Tumor Pathology 14 (1997), 125-129.

[52] J.R. Testa, M. Carbone, A. Hirvonen, K. Khalili, B. Krynska, K. Linnainmaa, F.D. Pooley, P. Rizzo, V. Rusch and G.H. Xiao, A multi-institutional study confirms the presence and expression of simian virus 40 in human malignant mesotheliomas, Cancer Research 58 (1998), 4505-4509.

[53] S. Weggen, T.A. Bayer, A. von Deimling, G. Reifenberger, D. von Schweinitz, O.D. Wiestler and T. Pietsch, Low frequency of SV40, JC and BK polyomavirus sequences in human medulloblastomas, meningiomas and ependymomas, Brain Pathology 10 (2000), 85-92.

[54] H.N. Zhen, X. Zhang, X.Y. Bu, Z.W. Zhang, W.J. Huang, P. Zhang, J.W. Liang and X.L. Wang, Expression of the simian virus 40 large tumor antigen (Tag) and formation of Tag-p53 and Tag-pRb complexes in human brain tumors, Cancer $\mathbf{8 6}$ (1999), 2124-2132.

[55] W. Zimmermann, S. Scherneck and E. Geissler, Quantitative determination of papovavirus IgG antibodies in sera from cancer patients, labworkers and several groups of control persons by enzyme-linked immunosorbent assay (ELISA), Zentralblatt für Bakteriologie, Mikrobiologie und Hygiene 254 (1983), 187-196. 


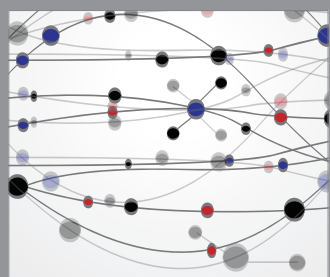

The Scientific World Journal
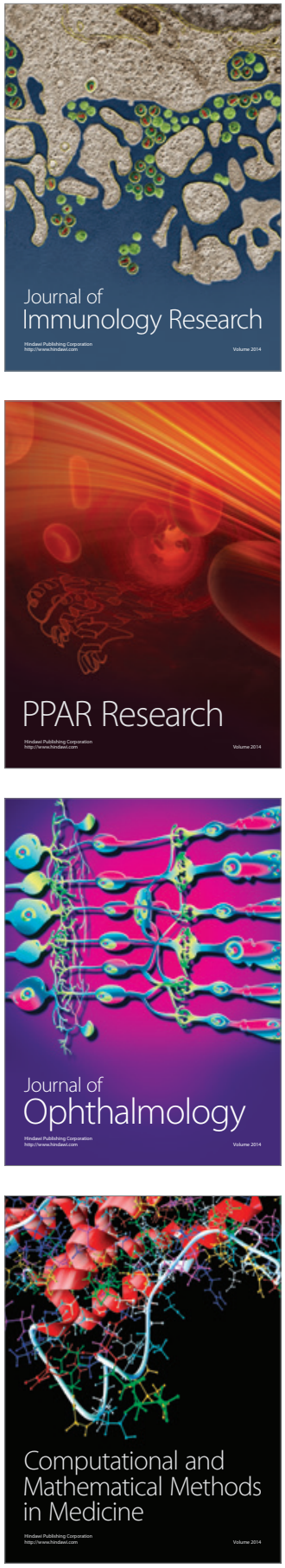

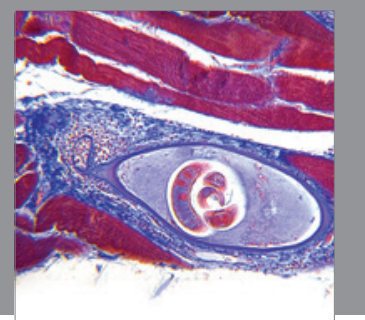

Gastroenterology

Research and Practice
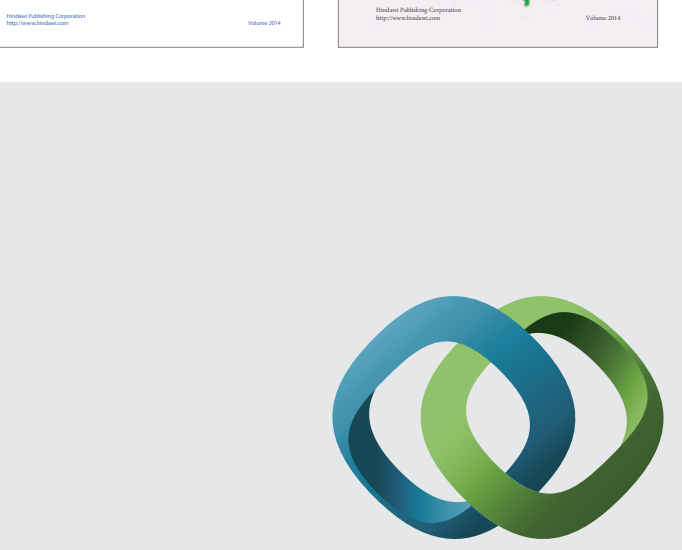

\section{Hindawi}

Submit your manuscripts at

http://www.hindawi.com
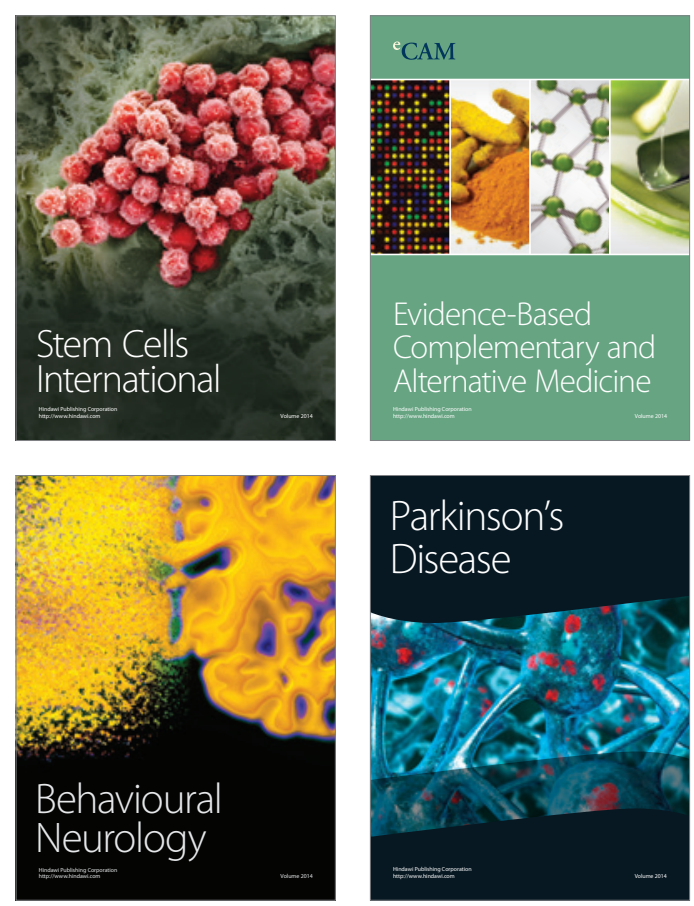

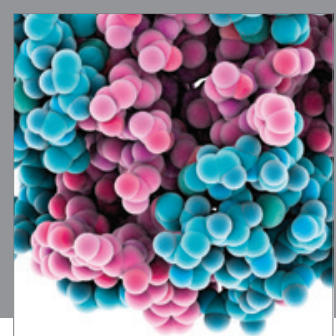

Journal of
Diabetes Research

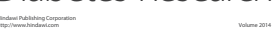

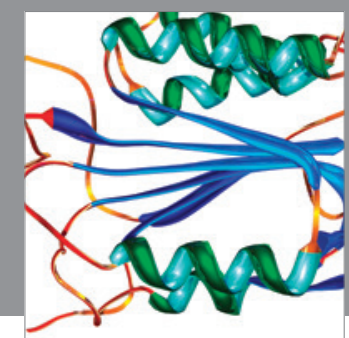

Disease Markers
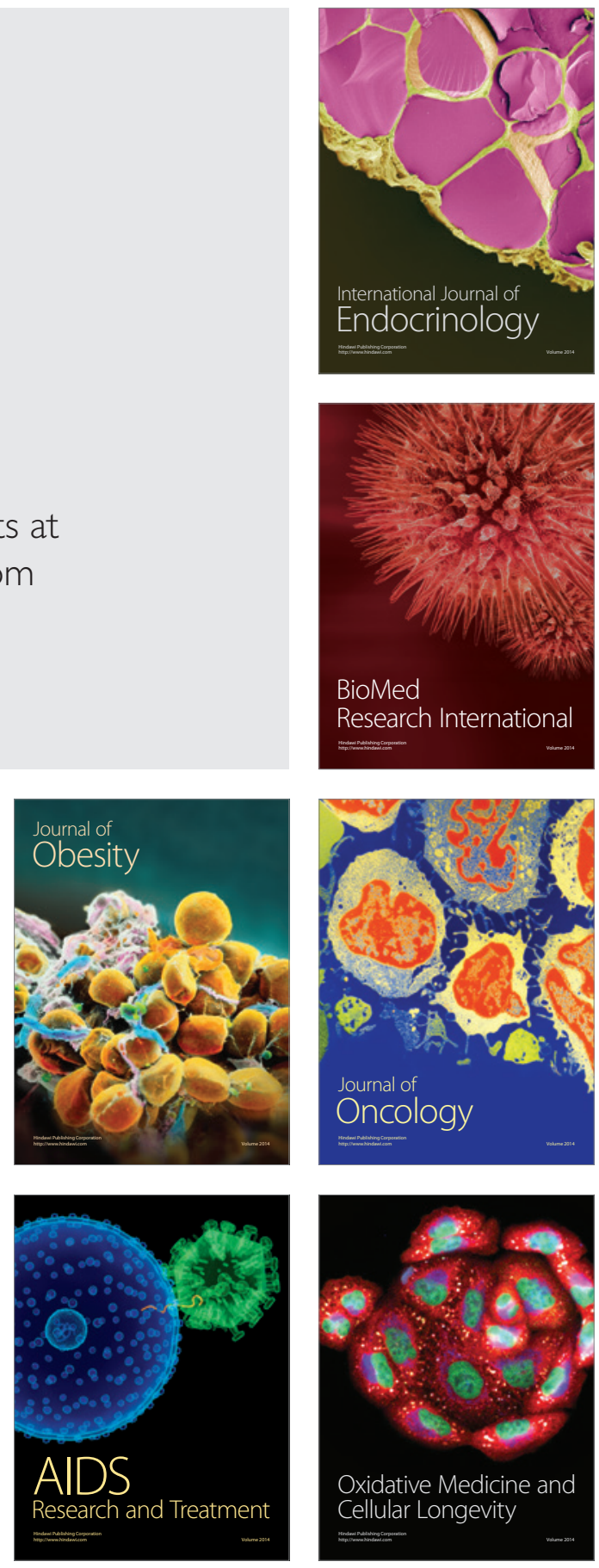